\title{
As contribuições da civilização egípcia na literatura e na educação: primeiras relações históricas entre texto verbal e texto não verbal'
}

Las contribuciones de la civilización egipcia en la literatura y en la educación: primeras relaciones históricas entre texto verbal y texto no verbal

Egyptian Civilization's Contributions to Literature and Education: First Historical Relationships between the Verbal and Nonverbal Text

\author{
GABRIELA CRUZ VÁSQUEZ \\ Universidad Autónoma de Baja California \\ México \\ ADRIANA PASTORELLO BUIM ARENA \\ Universidade Federal de Uberlândia \\ Brasil \\ cruz.gabriela@uabc.edu.mx \\ adriana@faced.ufu.br
}

(Recibido: 27-O2-20I6; aceptado: $02-06-2017$ )

Resumo. $O$ objetivo deste estudo é o de identificar as contribuições da civilização egípcia na literatura e na educação a partir da união do texto verbal e do texto não verbal em uma única obra, que foi uma das características nas estruturas literárias da civilização do Antigo Egito. Para discutir esse tema utiliza-se um documento histórico, o Papiro do Livro dos Mortos de Ani, tendo como foco de investigação o paradigma indiciário na decifração dos signos textuais e dos signos visuais. Mediante uma análise interpretativa são identificadas as relações entre o verbal e o não verbal nesse documento histórico para verificar suas contribuições, intenção didática, colaboração disciplinar, qualidade de fonte histórica, eternidade e reinvenção, complementariedade, autonomia e independência, o mágico, o maravilhoso e o sagrado, as quais poderiam ser integradas à literatura e à educação contemporânea.

Palavras-chave: texto verbal; texto não verbal; civilização egípcia; literatura do antigo Egito; literatura e educação atual.

\footnotetext{
${ }^{\text {I }}$ Para citar este artículo: Cruz Vásquez, Gabriela y Buim Arena, Adriana Pastorello (2OI7). As contribuições da civilização egípcia na literatura e na educação: primeiras relações históricas entre texto verbal e texto não verbal. Alabe 16. [www.revistaalabe.com] DOI: IO.I5645/Alabe2OI7.I6.8
} 
Resumen. El objetivo para este estudio es identificar las contribuciones de la civilización egipcia en la literatura y en la educación a partir de la unión de texto verbal y texto no verbal en una única obra, que fue una de las características en las estructuras literarias de la civilización del Antiguo Egipto. Para discutir el tema se utiliza un documento histórico, el Papiro del Libro de los Muertos de Ani, teniendo como foco de investigación el paradigma indiciario en el desciframiento de los signos textuales y de los signos visuales. Mediante un análisis interpretativo son identificadas las relaciones entre lo verbal y lo no verbal en ese documento histórico para verificar sus contribuciones, intención didáctica, colaboración disciplinar, cualidad de fuente histórica, eternidad y reinvención, complementariedad, autonomía e independencia, magia, lo maravilloso y lo sagrado, las cuales podrían ser integradas a la literatura y a la educación contemporáneas.

Palabras clave: texto verbal; texto no verbal; civilización egipcia; literatura del antiguo Egipto; literatura y educación actual.

Abstract. The union between the verbal and nonverbal texts in a single work of art is one of the characteristics of literary structures of the Ancient Egypt civilization. Historical documents from that civilization are used to approach the topic. The focus of the research is the circumstantial paradigm of deciphering textual and visual signs. Relationships between verbal and nonverbal cues in one of the main works of art of that civilization are identified through an interpretive analysis. These relationships could be integrated into contemporary literature and education.

Keywords: verbal text; nonverbal text; egyptian civilization; ancient Egypt literature; contemporary literature and education. 


\section{Introdução}

O Antigo Egito, aquela civilização na qual o coração era o sol ou centro do universo humano, conquista-nos pela magia e pelo maravilhoso presentes em sua cultura, sua arte, sua religião e sua literatura. Os egiptólogos dos últimos cinco séculos têm mencionado em suas obras que grande parte dos tesouros desta antiga civilização se encontra dispersa em todo mundo hoje em dia. Saqueadores de tumbas, ladrões e vendedores ilícitos daquelas relíquias sagradas profanaram uma das partes da história mais importante para o entendimento de nossas origens como Humanidade.

Dois elementos foram superiores a qualquer relíquia, a qualquer saque e, inclusive, ao tempo. Ambos elementos pareciam vaticinar o futuro de Egito e os perigos aos quais sua cultura estaria exposta na época atual. Estes elementos, da mão, são o maior tesouro herdado por esta civilização e que, ao mesmo tempo, nos permitiram reconstruir esse passado de que todos nós fazemos parte. Referimo-nos à escrita e à pintura.

A união da escrita e da pintura em um todo durante essa antiga civilização é quiçá uma das relações históricas estruturadas mais antigas entre texto verbal e texto não verbal de que se tem conhecimento. Implicitamente, o escriba e o artesão foram as duas figuras que deram uma importância sagrada à relação entre escrita e imagem através de duas fontes de informação inesgotáveis para essa literatura: os monumentos (paredes, tumbas, obeliscos, pirâmides, templos e palácios) e o papiro.

O objetivo desse trabalho é identificar as contribuições dessa relação histórica entre o texto verbal e o texto não verbal que faz parte da literatura e da educação desta cultura, as quais poderiam ser consideradas no desenvolvimento atual das disciplinas mencionadas. Para isso, utiliza-se um dos documentos históricos mais emblemáticos do Antigo Egito, o Papiro do Livro dos Mortos de Ani, escrito durante a r9. ${ }^{a}$ Dinastia de Egito. Antes dessa análise interpretativa, apresentam-se os primeiros traços históricos do texto verbal e do texto não verbal no Antigo Egito, a independência, autonomia e complementariedade entre texto e imagem, as peculiaridades da literatura egípcia clássica e uma introdução ao Livro dos Mortos.

\section{Primeiros traços históricos do texto verbal e texto não verbal no Antigo Egito}

Historicamente, o império egípcio dividiu-se em três períodos: Antigo, Médio, Novo e Democrático ou período de declinação. As obras literárias de maior relevância foram escritas durante o Império Médio e o Império Novo. O vínculo entre a literatura e o ensino ou instrução, através das obras, esteve presente nos textos desses períodos, considerada a Idade de Ouro da literatura clássica egípcia. Essas obras anônimas utilizariam estruturas narrativas simples com personagens pouco desenvolvidos, sendo o objetivo principal dessa literatura educar. Esta intenção didática e esta ênfase nos argumentos das 
obras expressaram a preocupação dos antigos egípcios pela conduta humana, especialmente no aspecto religioso (Brunner-Traut, 2000; Lefebvre, 2003). $\mathrm{O}$ anonimato dessas obras convida-nos a nos aprofundarmos na importância do escriba como figura de transmissão do ensino sagrado ou divino, segundo a concepção da civilização egípcia.

A figura do escriba teve muita importância na sociedade e particularmente em templos e palácios. Pérez (2008) distinguiu o papel do escriba e do artesão, bem como sua estreita relação. $\mathrm{O}$ autor assinala que texto e imagem estiveram intimamente vinculados e que, em algumas ocasiões, resultou difícil diferenciar o trabalho do escriba daquele que fazia o artesão. Os textos produzidos desse trabalho conjunto decoraram os monumentos egípcios e foram reproduzidos em cópias mediante papiros.

Segundo a concepção egípcia, a escritura sagrada tinha vida própria. Os escribas utilizaram as palavras divinas, isto é, os signos hieroglíficos. Estes signos e tudo o que se representava junto a eles adquiria vida (Pérez, 2008), daí que a relação entre imagem e escrita, artesão e escriba, fora também sagrada e divina.

Uma das características dessa cultura é a relação entre exibição e texto, explica Pérez (2008), em que o texto exibia e comunicava uma autoridade e era também um meio de comunicação com os deuses. Isto poderia ser também uma brecha no início da relação entre escriba e artesão, ou seja, entre escrita e arte.

\section{Independência, autonomia ou complementariedade?}

As diferentes linguagens que utilizamos, verbais ou não verbais, existem para nos comunicar. Comunicar-se é uma ação comum, em que os códigos inventados para a expressão e suas necessidades podem ser verbais ou imagens (Teixeira de Aguiar, 2004). No caso particular dessa civilização, a função do texto verbal e do texto não verbal foi possibilitar a comunicação através do espaço e do tempo.

Pode ser aludido que os egípcios tinham plena consciência do plano espacial e do plano temporal com respeito a sua literatura e a sua arte. A escrita tornava possível a comunicação entre um emissor e um receptor que se achava fisicamente distante (Galán, 2004), como também a distância dos governantes ao povo ou a distância dos reis às altas divindades. Assim mesmo, a função dos textos egípcios em monumentos ou em papiros revela a consciência que eles tinham do tempo, do que no amanhã aconteceria. Segundo esse mesmo autor, esta consciência espaço-temporária é ainda mais evidente quando os egípcios optaram por utilizar primeiramente um suporte não perecível, como o foi a pedra nos monumentos, a diferença do papiro, cuja missão principal foi a reprodução fiel em cópias dos textos escritos e visuais, muitas vezes tomados dos mesmos monumentos.

Uma das primeiras contribuições da relação entre texto verbal e texto não verbal na literatura da civilização do Antigo Egito é a pretensão de ser em uma fonte histórica no futuro. As inscrições textuais e visuais pareceram ter como objetivo vencer o passo do tempo e se comunicar com audiências futuras. Parece também que os egípcios procura- 
vam informar a gerações do futuro o passado em que eles se converteriam. Possivelmente almejavam ter algum tipo de influência sobre certa audiência contemporânea (Galán, 2004).

Barthes (I995) estudou em Retórica da Imagem a reciprocidade e a complementariedade entre texto e imagem. Ambos confluem, como se de fragmentos se tratasse, em procura de um nível de comunicação superior. Ao relacionar texto e imagem é difícil determinar se uma imagem é somente uma redundância do significado do texto ou se a imagem leva a ele; ou se, pelo contrário, o texto contribui com informação ao significado da imagem.

Guimarães (20I3) indaga sobre essa mesma união palavra-imagem como função complementar para a conformação de um texto. A autora se questiona sobre a autonomia e a independência do texto e da imagem, assim também, conclui que a associação entre essas duas linguagens é o meio de maior eficácia para a interpretação dos sentidos que são transmitidos pelo texto.

Abordar os aspectos de independência, autonomia e complementariedade nos textos dessa civilização podem ser ponto de apoio para uma análise mais completa da arte e da literatura do Egito Antigo. Mas, antes de nos aprofundarmos propriamente nesses laços entre texto verbal e texto não verbal na literatura dessa cultura, é importante trazer à luz novamente a questão da reprodução da informação, isto é, o regime das cópias em pintura e em literatura. Recordemos que o primeiro meio de transmissão do texto verbal e texto não verbal utilizado pelos egípcios foi a pedra como tal nos diferentes monumentos. Simultaneamente, o papiro permitiu a reprodução dos textos em cópias. Ginzburg (2003) descreveu através de exemplos que o estatuto de uma cópia de literatura é muito diferente ao de uma cópia de pintura.

"Os supostos caracteres eternos da pintura e da literatura não têm que ver entre si” (Ginzburg, 2003: I22). O autor retoma o caso de Mancini, quem achou difícil utilizar os métodos usados na crítica textual na pintura, estabelecendo por princípio uma analogia entre $o$ ato de pintar e o ato de escrever. Ginzburg (2003) detalha que partindo dessa analogia, Mancini procurou ajuda em outras disciplinas. É por isto que as cópias manuscritas podem ser reproduzidas exatamente iguais ao texto, mas a cópia de um retrato de Rafael não poderia ser nunca exatamente igual, conclui o autor.

Segundo o anterior, o caráter eterno no texto verbal é superior que no texto não verbal. No entanto, a imagem continua com sua função complementar em relação ao texto verbal. Levar em conta esse aspecto é importante no estudo da relação entre signos verbais e signos visuais nas obras do Antigo Egito, pois é comum encontrar diferentes versões de papiros de uma mesma obra literária, onde o artesão que realizou as ilustrações que acompanham ao texto, reproduzidas pelo escriba, darão como resultado o texto único e irrepetível. 


\section{Peculiaridades da literatura egípcia clássica}

A História de Sinuhé, Textos das pirâmides, Textos dos sarcófagos, História dos dois irmãos e o Livro dos Mortos são, entre muitas outras obras literárias dessa civilização, as que tiveram e têm maior popularidade. O Livro dos Mortos é provavelmente a obra mais reproduzida da literatura egípcia, tanto pelos antigos egípcios como hoje em dia. Recordemos a ênfase do culto à morte dessa civilização e compreenderemos, ao mesmo tempo, não só a transcendência sagrada deste texto, senão também o ornamento e a riqueza das tumbas faraônicas e de reis egípcios de várias dinastias. Essa cultura atribuiu um grande valor ao culto à morte.

Para Brunner-Traut (2000), os textos literários egípcios são célebres não só por sua atitude intelectual, senão também por meio das visões, conjuros, práticas de magia e pelas imagens fragmentárias onde aparecem animais exóticos ou homens com cabeças de animal. Segundo Brunner-Traut (2000), essas histórias breves e cheias de fantasia serviram para a doutrinação do povo egípcio. Após essa intenção educativa, ficou relegada em um segundo plano a intenção recreativa.

Estilisticamente, as características dos textos da literatura egípcia correspondem a um modo de conhecimento intelectual primitivo. Esse tipo de conhecimento, descreve Brunner-Traut (200o), é o mesmo que vive no presente de todos nós, nos meninos, nos povos e nas etnias. A respeito, Lefebvre (2003) menciona que a literatura da época faraônica supõe geralmente uma leitura elementar, agradável, em que estão presentes o estranho e o exótico.

... el cuento egipcio se caracteriza por la unidimensionalidad de su trama, por su trazado de claros contornos, sus principios asociativos, la dura coexistencia de claridad y oscuridad, la simplificación de las figuras; por un esfuerzo mínimo de caracterización y objetivización de los contenidos de la conciencia; los personajes no se desarrollan, es más, apenas dejan entrever alguna emoción, y cuando lo hacen, sólo es por medio de formulaciones en blanco y negro. Los sucesos se representan objetivamente sin la participación del hablante, los lugares se denuncian por medio de símbolos o sólo por sus nombres, el tiempo está detenido o avanza de peldaño en peldaño, pero no progresa de modo continuo (Brunner-Traut, 2000: 32-33).

O valor dos argumentos e a intenção didática foram as prioridades na literatura dessa civilização. Mas, há uma característica quase inseparável, diz Lefebvre (2003), na literatura do Antigo Egito: o maravilhoso. O autor estabelece seis categorias de textos: cenário, mitológico, anedótico, filosófico, psicológico e maravilhoso. Destaca-se o aspecto maravilhoso nessa literatura, que é associado à magia, o qual desempenhou um papel preponderante para essa cultura; feiticeiros, proezas de magos, eventos extraordinários e misteriosos, milagres, animais que falam e sinais que predizem o futuro foram elementos recorrentes nas obras da literatura egípcia clássica (Lefebvre, 2003). 


\section{O Livro dos Mortos}

Nesse breve ensaio elegeu-se o Livro dos Mortos para indagar sobre as primeiras relações entre texto verbal e texto não verbal. Esta é uma obra escrita com hieroglíficos, nas primeiras versões existentes, e com ilustrações coloridas. Pode ser apreciado o trabalho conjunto do escriba e do artesão. Se poderá, assim, verificar quais são as contribuições dessa civilização na literatura e na educação.

Devido à importância da morte para essa cultura, existem muitas cópias ou versões em papiro do Livro dos Mortos, já que se converteu em uma ferramenta de grande valor para os egípcios. O britânico Ernest Wallis Budge (I857-I934) resgatou em Luxor (antiga Tebas, Egito) o Papiro do Livro dos Mortos de Ani que é considerada nesse ensaio como uma versão adequada para o tema em questão; é uma das versões melhor conservadas quanto ao texto escrito e às ilustrações; também a mais extensa que se descobriu até hoje em dia. Esta versão pertenceu a um escriba real chamado Ani, escrito ao redor da I9. . Dinastia de Egito. O destino final do Papiro do Livro dos Mortos de Ani foi realmente trágico, já que fora cortado em fragmentos por seu próprio descobridor apesar de ter sido encontrado integralmente completo e após ter sobrevivido intacto vários milhares de anos. Os fragmentos deste papiro permanecem em The British Museum desde i888.

O Livro dos Mortos é um texto religioso e teve uma grande valia, como já se mencionou, para esta civilização. Contém mais de uma centena de conjuros mágicos, hinos religiosos e conteúdos morais, diz Champdor (I963), quem também considera que o $\mathrm{Li}_{\text {- }}$ vro dos Mortos conservou sempre seu sentido primitivo de ferramenta mágica indispensável para atravessar todas as portas que levavam ao "Além" após a morte. Por tanto, este texto foi uma obra e um objeto que fez parte da existência dos egípcios.

As diferentes versões de papiros dessa obra funerária aparecem decoradas com ilustrações coloridas que faziam "alusão", diz Champdor (I963), ao conteúdo do texto. Não todas as versões têm os mesmos episódios, já que os escribas e os artesãos elaboravam uma cópia do Livro dos Mortos, segundo as necessidades particulares de seu futuro proprietário. Mas, tinha um episódio que não podia faltar nessas diferentes versões: a representação onde Anubis pesa em uma balança o coração do falecido ante o tribunal de Osiris (veja-se a Figura I) e as confissões negativas ante 42 juízes do Inframundo (Champdor, I963), estas últimas são um conjunto de máximas para a existência do ser humano que aspirava à felicidade absoluta após a morte. 


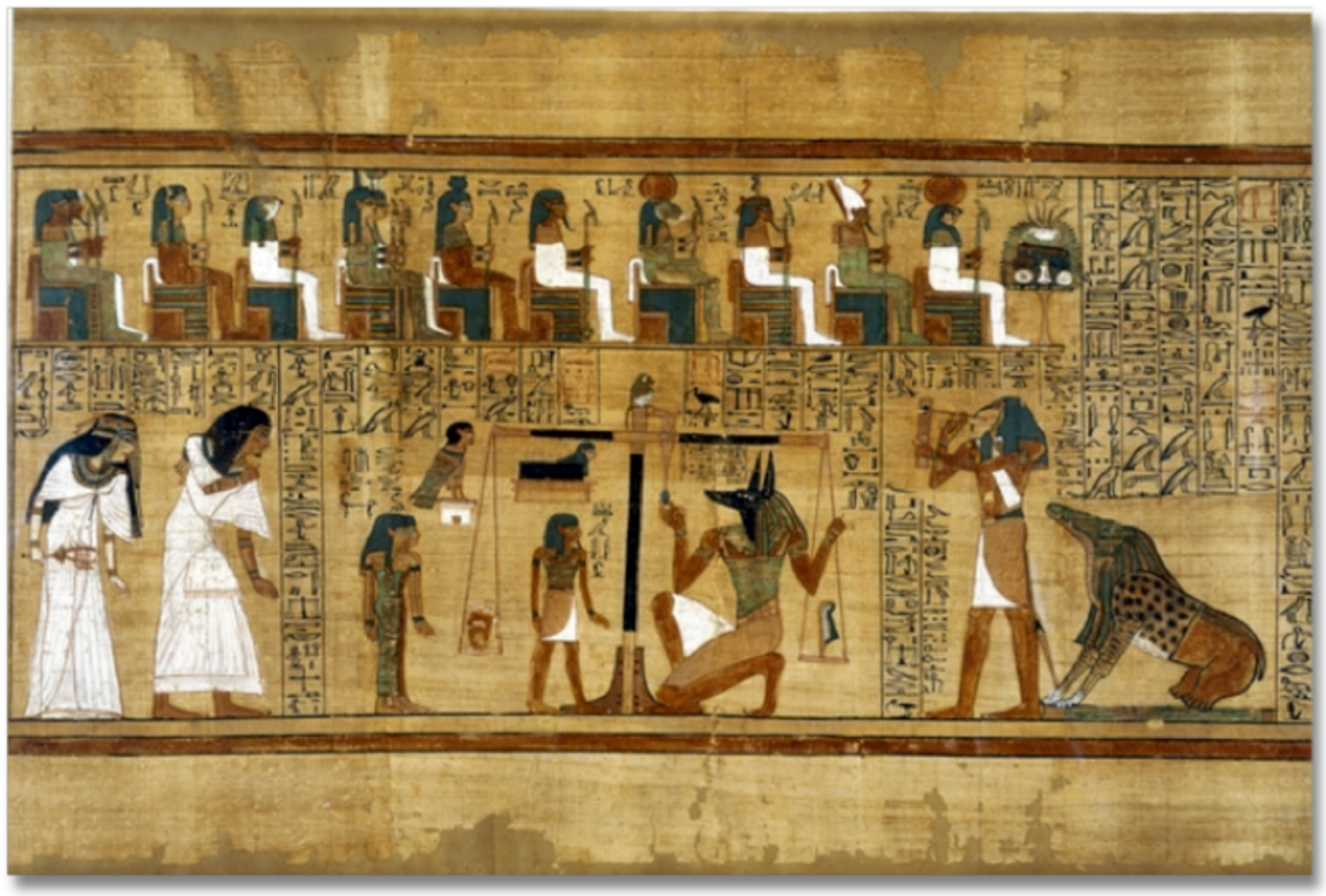

Figura I. "Papyrus from the Book of the Dead of Ani. The judgement of the dead in the presence of Osiris (Thebas, Egypt, Igth Dynasty, around I275 BC)"

Fonte: www.britishmuseum.org/explore/highlights/highlight_objects/aes/p/book_of_the_dead_ of_ani.aspx

\section{Contribuições do Papiro do Libro dos Mortos de Ani na literatura e na educação}

Com base no Papiro do Livro dos Mortos de Ani podem ser nomeadas as primeiras contribuições históricas com relação ao texto verbal e ao texto não verbal. Descrevem-se aqui brevemente essas contribuições considerando suas qualidades particulares. As contribuições foram estabelecidas com base na informação das primeiras fontes bibliográficas preliminares citadas ao longo deste ensaio, a observação de indícios e a análise interpretativa de fragmentos dessa versão particular no Papiro do Libro dos Mortos de Ani, recolhidos e visualizados no site do The British Museum. Assim poderão os leitores que tenham interesse nesta relação de linguagens vislumbrar futuros estudos com maior profundidade bibliográfica e aproximações que aprofundem sobre o texto verbal e o texto não verbal nas antigas civilizações da humanidade.

Segundo a análise interpretativa desse papiro que realizamos mediante o paradigma indiciário, são sete as contribuições do Papiro de Ani da civilização do Antigo Egito que identificamos para o estudo da literatura vinculada à educação, as quais nomeamos aqui qualidades: a qualidade de intenção didática integrada, a qualidade de colaboração disciplinar integrada, a qualidade de fonte histórica, a qualidade do eterno e a reinvenção, a qualidade da complementariedade, a qualidade da autonomia e a independência e, por 
último, a qualidade do mágico, do maravilhoso e do sagrado. Consideramos que essas sete qualidades identificadas nesse papiro poderiam ser integradas ao estudo do vínculo entre a literatura e a educação contemporâneas, seja no ensino da literatura ou na criação literária com fins didáticos de hoje em dia.

Intenção didática integrada. A intenção principal da literatura egípcia clássica foi o ensino e a instrução moral e religiosa com ênfase na morte. Esta intenção didática integrada foi plasmada mediante a colaboração íntima de duas disciplinas, a escrita e a arte; o trabalho conjunto e integrado do escriba e do artesão no Papiro do Livro dos Mortos de Ani parece ter sido bem planificada e bem estudada antes da produção do texto completo. Na atualidade, esta qualidade didática integrada poderia ser útil no ensino e na criação literária porque convida a combinar fins de instrução em uma única obra, pois é uma qualidade que poderia fazer frente aos problemas de convivência escolar, multiculturalismo e respeito à diversidade cultural.

Colaboração disciplinar integrada. Com respeito à qualidade de colaboração disciplinar integrada, o papiro ensina-nos, já desde a Antiguidade, a importância do uso de diferentes Belas Artes em uma única obra, tal como ocorre neste documento histórico com o uso harmonioso da literatura e das artes plásticas. Isso naquela época. No entanto, parece-nos transcendente mencionar o avanço que tem acontecido no desenvolvimento das artes plásticas e visuais, as quais têm integrado elementos da ciência e da tecnologia para a elaboração de trabalhos artísticos, por ser uma qualidade que nos convida a fazer uso das inovações contemporâneas para ensinar a literatura e gerar obras literárias e, assim, fazer frente à interdisciplinaridade que vivemos na atualidade na busca para compreender nossa própria realidade.

Autonomia e independência. Um dos primeiros aspectos que realçam nesse papiro são os contornos recorrentes nas ilustrações, os quais pareceriam um detalhe insignificante, no entanto, eles denotam independência entre a parte escrita e a parte da imagem; mas, existe também autonomia linguística do texto verbal. Apesar desta independência que se observa entre o trabalho do escriba e do artesão quanto a suas produções, há ao mesmo tempo uma qualidade da complementariedade entre ambas, já que há equivalência quanto ao conteúdo temático do texto verbal e do texto não verbal. Esta é uma das qualidades mais difíceis de conseguir em uma obra artística que utiliza diferentes disciplinas da arte. Quando lemos um livro de literatura infantil, por exemplo, veremos que não é uma tarefa fácil encontrar uma cumplicidade artística entre a visão de mundo do escritor e a visão de mundo do ilustrador. Portanto, é uma qualidade que consideramos valiosa no ensino da literatura e na criação literária com fins didáticos, pois há implícita nela valores sociais, como o respeito e a tolerância a outras formas de pensar e a diversidade cultural na literatura e na educação de nossos dias.

Complementariedade. Os signos verbais e os signos visuais, como fragmentos independentes de um significado maior, dão unidade à mensagem e à intenção comunicativa (veja-se a Figura 2). Existem também episódios do papiro em que pode ser apreciado que a parte escrita e as ilustrações se misturam, por assim o dizer, interatuam entre os 
rincões do papiro, isto é, a escrita atravessa a margem invisível própria da imagem, e vice-versa. Isto poderia detonar a luta "harmoniosa" entre a qualidade da independência e a qualidade da complementariedade do texto verbal e do texto não verbal.

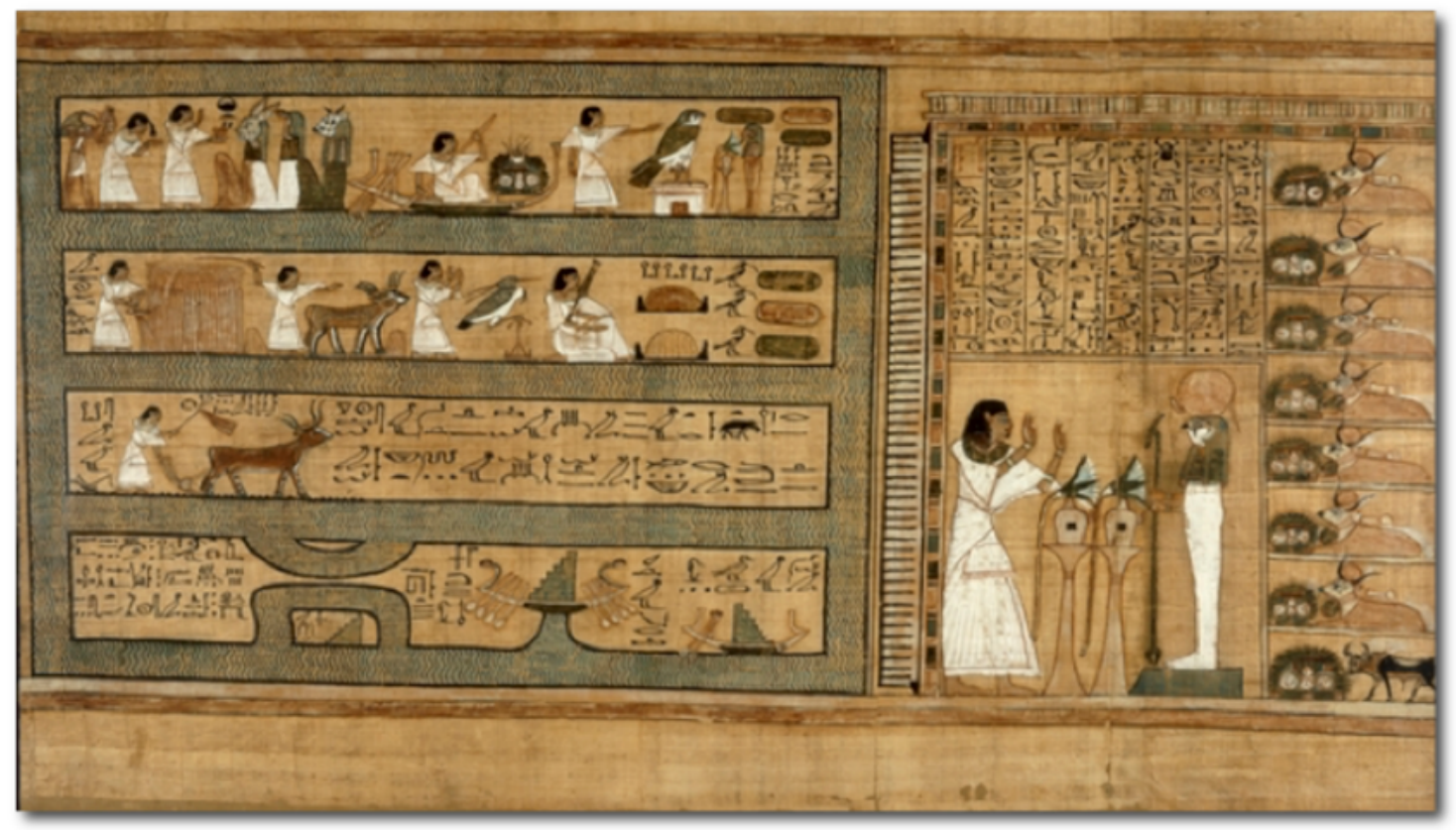

Figura 2. "Papyrus from the Book of the Dead of Ani. Vignettes showing agricultural scenes (Thebas, Egypt, I9th Dynasty, around I25o BC)”

Fonte:

www.britishmuseum.org/explore/highlights/highlight_image.aspx?image=ps3450Io.jpg\&retpa$\mathrm{ge}=\mathrm{I} 55^{2} 3$

Aprecia-se no Papiro do Livro dos Mortos de Ani alternância na localização das imagens com respeito ao texto escrito. Há episódios em que as ilustrações aparecem na parte superior, intermediária ou inferior do papiro. Às vezes, as imagens descrevem com precisão uma série de acontecimentos bem unidos sobre o trajeto de Ani no "Além" (veja-se a Figura 3), mas em outras ocasiões aparecem ilustrações unidas com o texto escrito que, mais que fazer alusão à história do texto verbal, duplicam visualmente a informação contida na parte escrita. Com respeito à finalidade das ilustrações que unem cuidadosamente os acontecimentos, essas parecem tentar levar ao leitor ao correto entendimento da sequência exata que há após a morte. Assim mesmo, não deve ser esquecido que a independência e a complementariedade, ainda que sejam opostas, são qualidades que devem coexistir nas obras literárias com fins didáticos da época atual, já que são as qualidades encarregadas de unir em uma única obra o texto verbal e o texto não verbal. 


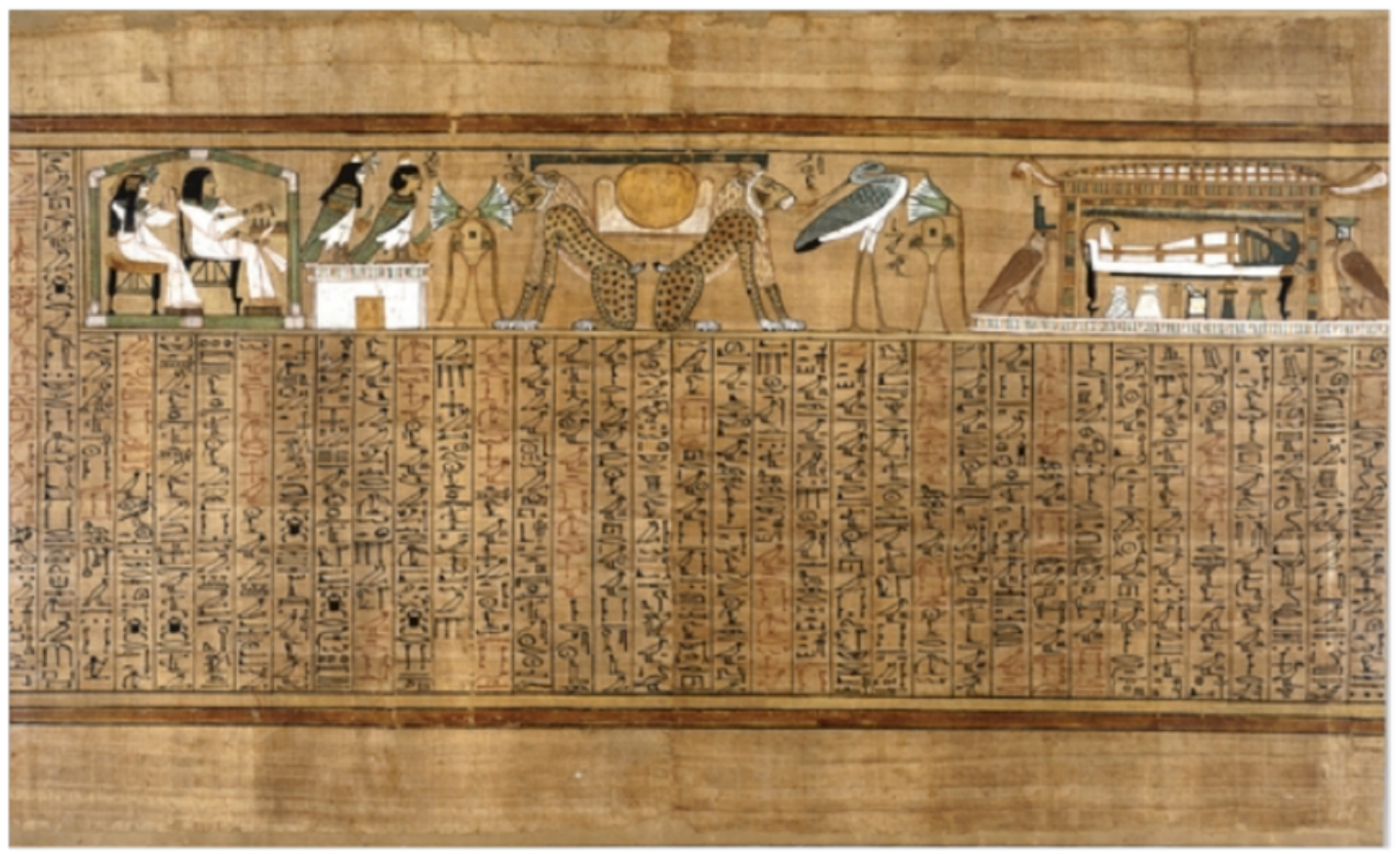

Figura 3. "Papyrus from the Book of the Dead of Ani. Chapter I7 of the Book of the Dead is a long and complicated spell, with an equally long history. It is essentially a statement of religious doctrines relating to the sun-god Re (Thebas, Egypt, I9th Dynasty, around I25o BC)"

Fonte:

www.britishmuseum.org/explore/highlights/highlight_image.aspx?image=ps275I53.jpg\&retpa$\mathrm{ge}^{\mathrm{e}}=\mathrm{I} 55^{24}$

O mágico, o maravilhoso e o sagrado. Outra das características mais destacadas da versão do Livro dos Mortos no Papiro de Ani é o uso brilhante e luminoso da cor nas ilustrações em contraste à parte escrita onde só se utiliza a tinta cor negra para o texto e a cor vermelha para os títulos. Segundo a concepção egípcia, a escritura sagrada tinha vida própria. A vivacidade e a luz que dão cor às ilustrações deste papiro fortalecem, por assim dizer, a capacidade imaginativa, isto é, ajudam ao leitor a dar "vida própria" ao texto como um todo e, inclusive, "movimento imaginativo" às sequências dos acontecimentos das personagens, que era uma das crenças que os egípcios tinham sobre o uso das imagens que acompanhavam os textos verbais. Pelo que poderíamos atribuir uma qualidade "mágica” às imagens do papiro, segundo a concepção egípcia, porque tinham como finalidade dar vida à representação verbal.

Enquanto as imagens guardam em si mesmas essa qualidade mágica, o texto verbal guarda em si a parte sagrada ou divina, se trata de palavras divinas, ditadas pelos Deuses que, junto às imagens com dita qualidade mágica, podem dar vida ao texto completo. É por isso que a imaginação do leitor terá uma vital importância na leitura do Papiro do Livro dos Mortos de Ani; é a imaginação do receptor a que permite o entendimento total do texto. O leitor ou receptor dá vida e movimento ao texto e às ilustrações, respectivamente, para convertê-lo em um todo. 
Neste estudo considera-se que as qualidades do mágico, do maravilhoso e do sagrado fortalecem a capacidade imaginativa e, portanto, o gosto pela leitura, pois são qualidades que não deveriam ser esquecidas ou que poderiam ser retomadas no ensino da literatura e na criação de obras literárias com fins didáticos.

O eterno e a reinvenção. A transmissão do ensino da literatura egípcia clássica teve como suporte, e como já se mencionou anteriormente nesse trabalho, os monumentos e os papiros. Ainda que pudesse parecer que a qualidade da eternidade própria dos monumentos superava a característica perecível do papiro, bem como sua característica de reproduzir facilmente a informação entre os cidadãos egípcios, resulta valioso recordar nestes momentos que as descobertas de papiros dessa civilização têm permitido reconstruir parte de sua história e precatar-se, ao mesmo tempo, da capacidade de reinvenção dos significados na união do texto verbal e do texto não verbal nestas obras literárias. Esta qualidade do eterno e da reinvenção, na atualidade, guarda relação com o uso de novos suportes de comunicação, simultaneamente dos formatos clássicos para a transmissão da informação.

Fonte histórica. Também, o uso de monumentos e de papiros parece assinalar uma necessidade inquietante com respeito à transmissão do ensino e do legado do Antigo Egito para futuras gerações, civilização que parecia vislumbrar, dentro de si, a existência de todos nós. É importante revalorizar nosso papel como sujeitos históricos quando ensinamos ou criámos literatura, re-significar a necessidade de contribuir, como professores ou alunos, à construção de um legado histórico, educativo e artístico.

\section{Conclusões}

Veremos que, nas diferentes versões de papiros do Livro dos Mortos, o texto escrito se reproduzirá integralmente igual, mas, foi aceitável a reinvenção da parte visual pelos antigos egípcios. Isto quer dizer que as formas e as cores das ilustrações guardam diferenças estilísticas entre as diferentes versões em papiro dessa obra literária e religiosa. Esta qualidade de reinvenção da parte visual opõe-se ao caráter eterno da parte escrita dessa obra da literatura egípcia clássica. Podemos, assim, interpretar que o texto verbal teve a responsabilidade de resguardar o propriamente eterno (proveniente dos Deuses), enquanto podemos atribuir que o texto não verbal manteve uma responsabilidade "mágica" para o desenvolvimento da imaginação. Com base nisso, o entendimento do sagrado mediante a literatura e o ensino para os egípcios teve dois pilares básicos: a eternidade na escrita e a imaginação nas imagens. Eternidade e Imaginação delimitariam e destacariam, assim, estas primeiras relações históricas entre o texto verbal e o texto não verbal.

Esse texto é um convite formal para integrar os conhecimentos construídos pelas civilizações antigas à investigação em educação e em literatura atuais através das sete contribuições preliminares resgatadas da literatura do Antigo Egito: a qualidade de intenção didática integrada, a qualidade de colaboração disciplinar integrada, a qualidade de fonte 
histórica, a qualidade do eterno e a reinvenção, a qualidade da complementariedade, a qualidade da autonomia e a independência e, finalmente, a qualidade do mágico, do maravilhoso e do sagrado. Também, um convite permanente a integrar os tempos passado, presente e futuro em nossa busca do conhecimento para compreendermos a nós mesmos como Humanidade. 


\section{Referèncias bibliográficas}

- Barthes, R. (1995). Lo obvio y lo obtuso. Barcelona: Paidós.

- Brunner-Traut, E. (2000). Cuentos del Antiguo Egipto. Madrid: Edaf y Albatros.

- Champdor, A. (1963). El libro de los muertos. Madrid: Albin Michel.

- Galán, J. M. (2004). El paso del tiempo y el recuerdo del pasado en el antiguo Egipto. RDTP, LIX, I, 37-55.

- Ginzburg, C. (2003). Huellas, raíces de un paradigma indiciario. En Tentativas (pp. 93-I55). México: Universidad Michoacana de San Nicolás de Hidalgo.

- Guimarães, E. (20I3). Linguagem verbal e não verbal na malha discursiva. Bakhtiniana, 8 (2), I24-I35.

- Lefebvre, G. (2003). Mitos y Cuentos egipcios de la época faraónica. Madrid: Akal.

- Papyrus from the Book of the Dead of Ani. (Igth Dynasty, around I25o BC). British Museum. Obtido o 3 I de julho de $20{ }_{5}$ desde < www.britishmuseum.org/explore/highlights/highlight_ objects/aes/p/book_of_the_dead_of_ani.aspx>.

- Papyrus from the Book of the Dead of Ani. (Igth Dynasty, around I275 BC). British Museum. Obtido o 3 I de julho de 2015 desde $<$ www.britishmuseum.org/explore/highlights/highlight_ objects/aes/p/book_of_the_dead_of_ani.aspx $>$.

- Pérez Largacha, A. (2008). El saber del palacio y del templo: las escuelas de escribas en el próximo Oriente Antiguo y Egipto. ARBOR Ciencia, Pensamiento y Cultura, CLXXXIV, 73I, 403-4II.

- Teixeira De Aguiar, V. (2004). Overbale o não verbal. São Paulo: UNESP. 